Georgetown University Law Center

Scholarship @ GEORGETOWN LAW

2018

\title{
The Strained Marriage of Public Debts and Private Contracts
}

Anna Gelpern

Georgetown University Law Center, ag1348@law.georgetown.edu

This paper can be downloaded free of charge from:

https://scholarship.law.georgetown.edu/facpub/2019

https://ssrn.com/abstract=3091194

117 Current Hist. 22-28

This open-access article is brought to you by the Georgetown Law Library. Posted with permission of the author.

Follow this and additional works at: https://scholarship.law.georgetown.edu/facpub 
"[S]overeign debt is a complex political institution, which cannot be reduced to creditor coordination or any other contract problem."

\title{
The Strained Marriage of Public Debts and Private Contracts
}

\author{
ANNA GELPERN
}

A $\mathrm{s}$ a new year begins, governments around the world are poised for another cycle of debt disputes and missed payments. Venezuela is stumbling into default after starving its people for years to pay foreign creditors. Its hard currency reserves are drying up under pressure from US sanctions as the government battles hyperinflation, runs out of things to sell to China and Russia, and tries to buy time with a wacky virtual currency scheme.

Meanwhile, Ukraine and Puerto Rico will each go to court in January to fend off debt collectors. Ukraine has appealed an English court decision that would enforce its debt to Russia as if it were an ordinary commercial contract, despite Russia's annexation of Crimea, crippling trade sanctions, and sponsorship of separatist conflict in eastern Ukraine. A fund known for making a fortune from suing Argentina has challenged a US federal law enacted in 2016 that promised bankruptcystyle debt relief for Puerto Rico. If the fund wins, hopes for a fresh start for the hurricane-battered commonwealth and an equitable resolution for its creditors would dim.

On the bright side, Greece plans to exit the multilateral lending programs that many of its citizens had come to associate with economic collapse, austerity, and loss of policy autonomy. It aims to return to the private financial markets in the fall of 2018. Looming in the background is its debt to euro area governments, which will take generations to repay.

Each of these crises is intensely political, even constitutional, but politics is barely visible in today's sovereign debt restructuring regime. This informal regime coalesced in the 1980s and 1990s

ANNA GELPERN is a professor of law at Georgetown University and a nonresident senior fellow at the Peter G. Peterson Institute for International Economics. around a relatively stable transatlantic core of governments, international organizations, and private creditor groups, and depended on coordination among them. Throughout this period, private capital flows grew in size and importance to sovereign finance. In response, debt contract reform moved to the forefront of the policy agenda, and quietly took over.

Private contracts are the foundation of private capital movements. The catch phrases "freedom of contract" and "sanctity of contract" capture the ideal: debtors and creditors freely agree on the terms of their relationship up front, and must abide by this private constitution in good times and bad. Domestic courts step in only to resolve disputes.

When governments borrow in the private financial markets, they enter into private debt contracts. These contracts are highly standardized, which makes them easy to trade. In a world where governments borrow primarily from the private markets, changing contracts is an appealing way to deal with sovereign debt crises. The trouble is, governments are very different from private debtors. Trying to solve public debt problems by changing private contracts is at best inadequate. At worst, it can backfire and complicate crisis response.

\section{CONTRACT LOGIC}

The logic of public debt policy investing so heavily in private contract design is intriguing. It holds that crises would be less frequent, less protracted, and less damaging if only debtors and creditors could tweak a few words in their IOUs. Well-designed contracts might even make governments prudent and creditors collaborative.

The idea has a long and respectable pedigree. In the 1930s, when the US Congress was debat- 
ing municipal bankruptcy legislation, experts at the League of Nations weighed the relative merits of a debt-restructuring treaty for governments against debt contract clauses that would let creditors voluntarily reduce their claims by majority vote. Unlike municipal bankruptcy, sovereign bankruptcy was a political nonstarter then, and remains one now. A treaty never came to pass; World War II put contract reform projects on the back burner, while private markets for most government debt remained frozen for decades. Contract reform came back when the private markets revived in the late twentieth century; it has prospered over time and across wildly different institutional contexts.

At the turn of the twenty-first century, a distressed sovereign would normally secure emergency funding from the International Monetary Fund (IMF), tied to economic reforms. The agreement would anticipate a mix of domestic savings and measures to boost revenue, new borrowing, and debt relief. The debtor would then seek concessions from its constituents: economic sacrifice from its citizens, debt relief or new money from its creditors. Different creditor groupsgovernments, banks, bondholders-held distinct claims on the debtor, and negotiated separately. The entire process was implicitly anchored in the IMF, and the whole system held together when each group linked its contributions to those of the others. The job of debt contracts was to coordinate private creditors and deter free riders.

This set of nonbinding but reasonably predictable practices evolved from one crisis to another, and delivered just enough relief to the debtors and returns to the creditors to preempt more radical proposals, especially a sovereign bankruptcy treaty. To be sure, the regime was far from perfect. It was notoriously slow, stingy, and unaccountable. By 2010, it showed signs of strain.

New private and government creditors, such as China, Russia, and the Gulf states, were only provisionally invested in the old restructuring institutions. The IMF shrank by comparison with private capital flows, and its ability to anchor crisis responses on its own was openly questioned. Regional safety nets emerged as complements and competitors to the IMF in Asia and in Europe. Meanwhile, contract reform gained visibil- ity and became firmly entrenched in the policy repertoire. Early in the European debt crisis, in November 2010, euro area governments promised to change their contracts as part of a new regional crisis management and liquidity support scheme.

The New York Times recognized the importance of contracts in a 2014 editorial: responding to US court rulings that directed Argentina to pay holdout creditors in full if it made scheduled payments on its restructured or new debt, the editorial called on governments to adopt majority amendment terms in their bonds to avoid Argentina's fate. Majority amendment clauses (also known as collective action clauses or CACs) typically set out a procedure by which creditors owed money under the same contract can vote to change the debt terms. For example, a supermajority of three-quarters might agree to reduce principal or defer interest payments. Recent variations on CACs allow creditors under multiple contracts to aggregate into a single voting pool. Versions of majority amendment found their way into most new sovereign bonds by 2017 .

For all their prominence and recent success, sovereign debt contracts are unlikely levers for reform, for several reasons. First, government promises are hard to enforce. No court can make a sovereign do as it is told, since national borders and sovereign immunity shield its assets and keep its officials out of jail. Why spend scarce policy resources finessing unenforceable boilerplate?

Second, standard-form bond contracts are notoriously hard to change. Academic studies confirm market reports that these contracts are "sticky"slow to assimilate new terms even if they would improve on the status quo. Sovereign bond contracts might be stickier than most, because their role in the financial system generally requires them to be actively traded. Forcing investors to pause and analyze new words might scare off buyers. It took years and several rounds of concerted intervention by world leaders to make majority amendment clauses the norm across the foreign sovereign bond markets. Yet their impact may be small or uncertain, depending on the precise formulation and other factors.

Third, private contracts are private. Unlike statutes and treaties, contracts are made behind closed doors between debtors and creditors, some of 
whom happen to be sovereign governments. International officials have no comparative advantage in drafting the terms, and no sure way to enforce compliance. Decentralization, lack of information, and coordination problems among governments and market participants make contracts an awkward policy vehicle.

\section{LEFT OUT}

Despite such practical objections, contracts remain popular because they can deliver some of the creditor collective action benefits of bankruptcy without arousing the same level of political hostility. For technocrats and politicians, contract reform has become a pragmatic problem-solving approach that does no apparent harm. Missing from this calculus is the idea that sovereign debt is a complex political institution, which cannot be reduced to creditor coordination or any other contract problem. The biggest risk of putting so much energy into contract reform lies not in contracts per se, but rather in what falls by the wayside.

Framing public debt as a private contract problem leaves essential questions outside the frame. Consider Venezuela, where no amount of tinkering with contracts would convince the government to secure enough debt relief from its creditors to feed its people. Consider Ukraine, whose president rushed to borrow $\$ 3$ billion from Russia shortly before he was driven from power and Russia annexed Crimea. His successors got stuck repaying a creditor that did its best to sabotage Ukraine's economy, boycotted restructuring talks, and sued to enforce the debt contract in an English court. Consider Greece, which enacted pathbreaking changes to its foreign bond contracts, and-after an elegantly executed restructuring of most bonds held by private creditors-was left with a mountain of debt to euro area governments.

In each case, better contracts might smooth the debt restructuring process or buy time to design a solution to the crisis; in no case are they themselves the solution. Using private bond contracts as a substitute for public institution-building does not simply leave core questions unaddressed. It can do new damage by encouraging free riders, undermining government accountability, and seeding future political conflict.

\section{FREE RIDING}

Hedge funds that make a killing by suing poor countries over defaulted debts are the bête noire of sovereign debt policy. These "vulture funds" have long supplied the core rationale for majority modification clauses in sovereign bonds, since they free ride on the sacrifices of other creditors and the country's citizens.

The fifteen-year battle between Argentina and a handful of funds in US federal courts validated the contract narrative. The most aggressive and patient vultures recouped more than 1,000 percent of their investment in 2016. Court sanctions that prompted Argentina to default on all its debt rather than pay the holdouts, and then eventually drove it to settle with them, hinged on a single clause. Judges stressed that debtors and creditors could avoid a bad outcome by changing their contracts. In response, financial industry groups worked hand in hand with policy makers to design and promote new model contract terms.

But vulture funds were not the biggest holdouts in the most recent sovereign bond restructurings. Instead, the honors went to the European Central Bank (ECB) in Greece and to Russia's sovereign wealth fund in Ukraine. In 2012, the ECB escaped haircuts on more than $\$ 60$ billion in Greek bonds identical to those that got written down by 60 percent in the hands of private creditors and Norwegian and Chinese government investment funds. (The ECB swapped its bonds for new ones with different serial numbers.) In a later submission to Germany's federal constitutional court, the ECB said it would vote against restructuring sovereign bonds in its portfolio, since it lacked authority to compromise its claims.

While Greece chose to stay in the euro area and keep paying the ECB, Ukraine tried to walk away from its debt to Russia. When the bond trustee sued on Russia's behalf, the English court acknowledged that it was not dealing with a garden-variety obligation. However, the judge would not consider Ukraine's claims that Russia had pressured it into borrowing the money and later undermined its capacity to repay. He held that claims of duress in the case involved matters of public international law and fell beyond the purview of local commercial courts-and that Russian interference with Ukraine's repayment was not expressly barred by contract. Because 
the debt took the form of potentially "transferable financial instruments" (Russia still held the lot), the court would not reach beyond "the four corners of the relevant contracts" to punish inequitable behavior.

Greece showed that contract form could be ignored to spare the ECB. Ukraine showed that contract form could be leveraged to Russia's advantage. Both free-riding opportunities arose from a mismatch between the impersonal, standardized contract form and the complex political relationship between the debtor and the creditor. Other central banks and sovereign wealth funds would be hard-pressed not to exploit such an opportunity where they had the power to do so.

Ideal bond contracts are a little like money, supremely easy to transfer and trade without regard to the particular debtor-creditor relationship. Yet government-to-government lending is mixedmotive, never entirely arm's length, impossible to strip of political and policy considerations. Governments have extrajudicial means of protecting their interests, using diplomacy, trade, or military force.

A creditor unconstrained by commercial motives could be altruistic and patient, but could just as easily use its position to bully or extract strategic concessions from the sovereign debtor. It could go to court to embarrass the debtor, or cause political trouble, even if doing so made little financial sense. It does not need contracts to get paid, and it can choose to use contracts for commercial or noncommercial ends. In today's sovereign debt restructuring regime, a government creditor holding a bond can choose to act as an official or private creditor, and change its mind at any time.

Looking back at the Greek and Ukrainian experiences, it should come as no surprise that bond contracts are ill-equipped to manage political conflict. No amount of drafting finesse can change that. When clauses designed to coordinate a discrete subset of creditors are called on to respond to constitutional and geopolitical crises, they will fall short, and may backfire. This does not mean that contracts or contract reforms are worthless, but rather that they are a limited tool, which tends to get overloaded in sovereign debt for lack of politically palatable alternatives.

\section{TWILIGHT IN CARACAS}

If the contract form was ignored in Greece and abused in Ukraine, it is even more vulnerable in Venezuela. The sovereign and the state oil con- glomerate PDVSA together owe at least $\$ 60$ billion to bondholders, somewhere in the neighborhood of $\$ 25$ billion to China and $\$ 10$ billion to Russia, and billions more to investors and suppliers. The increasingly repressive and erratic government of President Nicolás Maduro has shrunk imports, abandoned investment, and failed to meet the basic human needs of its population in an effort to keep up the debt payments while the economy crumbles.

It is hard to explain why a leftist government would take food and medicine from the poor to pay Wall Street, which has long priced in default. Venezuelan officials may believe that default would put the country's oil tankers at risk of being seized by creditors on the high seas, cut off export revenues, and endanger the regime's hold on power. Rumors of bonds owned by insiders and other corrupt schemes have been floating around for years. Whatever the reason, the case highlights an underappreciated dimension of sovereign immunity: just as no one can force a sovereign to pay on command, no one can force it to default.

In Venezuela's case, it has not been for lack of trying. The United States has ratcheted up sanctions against Venezuelan entities and Maduro associates. After the government sidelined the opposition-dominated legislature in 2017, US sanctions effectively blocked it from issuing new debt or renegotiating the old bonds. By year's end, sanctions had begun to interfere with debt payments and attempts to settle trade and investment disputes.

China and Russia kept the Maduro government afloat for several years with cash infusions and critical inputs, mostly in exchange for future oil deliveries. Both sought dirt-cheap oil and strategic assets, but their case for sponsorship weakened over the course of 2017 as oil production fell and Maduro lurched from one desperate measure to the next. Chinese and Russian entities have sued; Russia even seized a tanker in the Caribbean. With relatively small amounts of unpaid invoices at stake, the government was quick to settle. Such lawsuits would not trigger regime change; they do, however, point to looming financial constraints and aggressive enforcement.

Contracts have been marginal to Venezuela's story so far, notwithstanding voluminous commentary on its bond terms in market reports and academic publications. Few expected the Maduro government to last this long, or to default and still hang on to power. Many foreign creditors had planned on a new market-friendly government, the 
lifting of sanctions, a comprehensive workout under the auspices of the IMF, and maybe bankruptcy for PDVSA. In this scenario, contracts would take center stage. For as long as default happens under the current government and against its wishes, the restructuring path is muddled.

While bondholders are still debating whether the government is in default, new investor and supplier lawsuits crop up daily. Venezuela has settled a handful, including one brought by a Canadian firm that pursued an especially skillful and aggressive litigation strategy. The terms were reportedly favorable to the investor-which should encourage imitators-but details are sketchy.

The financial and legal terms of China's and Russia's contracts are also a mystery. Both governments gave Venezuela breathing room in the past, but there is no guarantee that they would participate in a broad-based restructuring. If they do, they might decide to treat their dealings with Venezuela and PDVSA as private secured debts, as trade claims for oil deliveries, or as foreign aid. Each of these implies a different restructuring process, repayment priority, recovery value, and free-riding opportunity. China, Russia, suppliers, or direct investors could plausibly get paid in full from remaining reserves, or strip valuable assets. Then bondholders, with their state-of-the-art contracts, would be left fighting for crumbs.

In the twilight before default, the fact that so many contracts are nonexistent or unknown, and so many others could be changed retroactively on a whim, is a symptom of the continuing deterioration of the old restructuring institutions.

\section{THE GREEK LABYRINTH}

When a newly elected Greek government discovered in 2009 that its predecessors had falsified debt and deficit statistics, the country plunged into a catastrophic debt crisis that quickly spread across Europe. Greece suffered eight years of economic collapse, political strife, and societal breakdown. At long last, it seems to have turned the corner. In December 2017, the government exchanged more than $\$ 35$ billion in old bonds for new ones with lower interest rates and longer maturities. It plans to "graduate" from the IMF and European rescue programs by the fall of 2018, and to sell new debt in the capital markets. It has attracted large-scale infrastructure investment, notably from China.
Nonetheless, unemployment lingers above 20 percent, and the total burden of Greek government debt ( $\$ 383$ billion in 2017) is stuck at around 180 percent of gross domestic product; more than twothirds is owed to euro area governments and institutions.

Greek debt to its European neighbors has been a source of tension within Europe and between Europe and the IMF. The IMF lost face over its failure to secure more debt relief from Greece's private creditors before 2012, for letting public funds be used to repay maturing debts to private creditors in 2010-11, and for apparently excessive deference to its "troika" partners, the European Commission and the ECB, in the Greek program's design. Since 2015, the IMF has stood accused of overcompensating for past errors: using its small share of the Greek financing package as a platform, the IMF has demanded deeper debt relief from euro area governments and institutions, and refused to compromise on what some European officials saw as minor differences in budget assumptions. Critics argue that the IMF is needlessly dwelling on the size of the Greek debt stock, when payment flows are all that matter.

Euro area members have made impressive concessions. Public-sector creditors have extended maturities and reduced interest rates on Greek debt many times since the 2012 bond restructuring, so that Greece has hardly any payments due to them for years to come. This helps explain private creditors' willingness to buy short- and medium-term Greek debt. Researchers estimate that Europe has written off more than half of its claims, in presentvalue terms.

A recent working paper by the Peterson Institute for International Economics argues that extending principal repayment even farther into the future, as far as 2080, would help make Greek debt sustainable. But apart from disagreement on the economic merits of further rescheduling, legal and political imperatives prevent European governments from admitting to their citizens that they have granted any debt relief, lest they be accused of subsidizing a profligate neighbor in violation of a European treaty prohibition on fiscal transfers. The same barriers stand in the way of principal reduction.

Debt sustainability analysis that focuses solely on payment flows and the present value of Greek 
obligations ignores a central political dimension of debt. The debtor-creditor relationship is inherently hierarchical. For Greece, as for many lowincome countries without market access, being in debt to governments and international organizations comes at the cost of policy autonomy.

From the creditors' perspective this is a necessity, since they do not trust the debtor to manage its economy. The debt obligation and the associated policy conditions offer a means of control. For European creditor governments, postponing principal repayment has three big advantages over principal reduction: it would achieve debt relief and facilitate private market access for Greece, establish a platform to monitor Greek policy performance until the debt matures, and allow creditor governments to tell their own citizens that they are getting repaid in full (at least nominally).

The downside of postponing repayment rather than reducing the principal is that it risks perpetuating what has become a toxic debtor-creditor relationship for generations. If the goal is to build a healthy political community in Europe, it is far from obvious that avoiding bailouts today is worth the cost of entrenching inequality in the long run.

\section{UNEQUAL RELATIONSHIP}

Contrary to the image of a fresh start, debt restructuring often reduces policy autonomy for sovereign debtors, particularly when the creditors are foreign governments or international institutions. Debt problems are presumptively attributed to economic mismanagement. It seems axiomatic that a durable recovery and a return to debt sustainability require policy reform, which in turn requires monitoring and enforcement by someone other than the voters who failed at it to begin with. The debtor-creditor relationship is well suited to the task.

Conditionality, monitoring, and enforcement are not necessarily altruistic. Government creditors are in the business of lending taxpayer funds to achieve public policy objectives, and are accountable to their citizens for the results. They are not necessarily accountable to the borrowing government or its people, even though they may effectively take over that government's policy functions, and even though citizens of debtor and creditor nations may have different policy preferences.

Greece again presents a stark example. Reform programs designed by its public sector creditors often included assumptions about tax and privatization revenues that were criticized as unreal- istic and projections of growth, unemployment, and market access that turned out to be wrong by a wide margin. Multiple studies and internal assessments highlight such errors, which may have reflected political pressure, excess optimism, or a mix of factors. More recently, Europe and the IMF have had trouble agreeing on a single set of assumptions for the Greek program.

The consequences of wrong assumptions and bad policy design fall overwhelmingly on the debtor, along with the cost of its own poor policy performance. Under the circumstances, creditors have limited incentives to come up with good designs and realistic projections, unless they are facing payment default or reputational damage of existential proportions.

Contract tools can help reallocate the burden of policy design and performance-for example, by building in triggers for automatic debt relief if policy assumptions turn out to be wildly off the mark. Debt relief need not absolve sovereign debtors of the consequences of economic mismanagement, but it can be calibrated to share responsibility more equitably, and to create incentives for citizens of creditor countries to hold their own representatives to account when they design policies for citizens of other countries. While public sector creditors can profit by adapting private contract techniques, technique can never be the whole story. Allocating policy responsibility between debtors and creditors, and calibrating loss-sharing triggers, are political decisions about distribution. Contracts merely implement them.

\section{DEBT POLITICS}

Government debt is an inherently political and constitutional project. Alexander Hamilton famously argued that federal debt would bind a loose confederation of states into a nation, and help invest the young nation's commercial elites in the fortunes of its federal government. Public debt, whether owed to governments or private creditors, can serve as the foundation for domestic money and credit, fuel economic and political development, and cement international alliances. Foreign debt-owed to the governments of France and Spain, and to Dutch bankershelped finance US independence from Britain. It also featured prominently in nineteenth-century colonial conquests and twentieth-century imperial breakups.

Against this historical background, the rise of private contract design to its preeminent place in 
sovereign debt policy at the start of the twentyfirst century seems anomalous and risky. The dominance of private international capital markets calls for more attention to contracts, but not to the exclusion of building public institutions. The limits of debt contracts as a policy tool have become apparent as the existing regime for sovereign debt restructuring is challenged by the demise of legal and geographic boundaries, and the rise of new creditors with no stake in old institutions. Established creditor coordination practices are breaking down, and the sovereign debt restructuring regime suddenly looks fragmented and barren, devoid of shared norms and values.

Neither debtors nor creditors, public or private, care to talk about the political core of sovereign debt. It brings up uncomfortable questions of legitimacy and distribution, and reveals the limits of sovereignty that no one wants to admit. For experts in finance ministries and international institutions, politics can be a source of uncertainty and an obstacle to optimal technocratic solutions.

The unfolding crisis in Venezuela highlights the urgency of addressing sovereign debt politics head on. Years spent refining contract terms to smooth a consensual restructuring process and rejecting calls to institutionalize common standards for responsible lending and borrowing, including criteria for marking debt issued by oppressive regimes as "odious" and making it uncollectable, have left the international community ill-prepared to deal with a corrupt government that starves its people and sells assets in secret to pay its creditors. Is the Maduro regime "odious"? Absent international consensus on the answer, US bilateral sanctions complicate life for the Venezuelan government, but they also make for an easy scapegoat and bolster its popularity at home.

Failure to convince new creditors such as China that reformed debt-restructuring institutions can serve their interests encourages free riding. Why should China seek international cooperation to collect from Venezuela, Congo, or Angola if it can get a better deal on its own, just as the ECB did in Greece? Private law doctrines that banished politics from sovereign-debt contract disputes created an opening for Russia to use English courts to harass Ukraine.

Engagement with politics and public institution-building does not dictate the embrace of par- ticular institutional forms, such as treaty-based bankruptcy. Puerto Rico's troubles illustrate that bankruptcy as such is not a silver bullet, and that political forces can twist bankruptcy tools beyond recognition.

The US Congress wrote a special bankruptcy law to help Puerto Rico work its way out from under a mountain of debt. The debt itself came of decades of mismanagement, which is hard to separate from the deeply dysfunctional relationship between the island commonwealth and the United States, infected with colonial dominance, economic dependency, and distortionary fiscal policies. No bankruptcy law can fix all that, and the federal law enacted in 2016 does not try. But it does go the extra mile for one constituencyprivate bondholders-by tiptoeing around such basic bankruptcy tasks as gathering all competing claims in a single process, arranging them in an intelligible order of distribution, and overriding individual contracts to assign each claim a fair share of the assets, which would give the island a fresh start.

Durable reform requires constituents invested in the project. This means, among other things, making vast improvements in public disclosure of sovereign debt terms and restructuring outcomes, developing coordination mechanisms among regional and international safety nets, and elaborating the standards for debt legitimacy, sanctions, and equitable loss sharing.

Public debt cannot be left entirely or even mostly to private ordering. It is bigger than any one contract dispute. It has too many core constituents outside the four corners of the contract, including taxpayers, pensioners, government workers, bank depositors, and other governments, to name just a few. This is not a complex or controversial insight, but turning it into tractable policies is technically daunting and politically risky.

Modern sovereign debt history is littered with stalled and abandoned treaties and institutions, from the League of Nations to the United Nations and the IMF. The temptation to turn to private contract adjustment as an alternative is irresistible. It is time to recognize this as a false alternative: even if it makes good sense as a matter of contract design and helps buy time for political compromise, it can never be that compromise, for the simple reason that public debt is irreducibly public. 